\title{
Analysis of the Legal Measures Concerning Risk Assessment and Control for High-Speed Rail: Experience and Lessons from the European Union
}

\author{
Kai Liu ${ }^{1}$ \\ ${ }^{1}$ Associate Professor, Law School of Jiangsu Normal University, China \\ Correspondence: Kai Liu, Room 608, Building 16, No.101 at Shanghai Road, Xuzhou City, Jiangsu Province, China.
}

Received: July 14, 2020

doi:10.11114/ijsss.v8i5.4962
Accepted: August 3, $2020 \quad$ Available online: August 5, 2020

URL: https://doi.org/10.11114/ijsss.v8i5.4962

\begin{abstract}
In a context of the emerging risks that may lead to the high speed rail accidents and so the deaths, the question is to know what the roles of different actors prescribed in the legal system and what instruments have been established, and whether the legal framework is sufficient to promote risk assessment. This research studied the European Union legal system and pointed out its experience that could be enlighting as well as its weaknesses.
\end{abstract}

Keywords: high speed rail, legal mechanism, risk assessment, obligations, safety management system

\section{Introduction}

As defined by International Union of Railways, High Speed Rail (HSR) is a rapidly expanding new transport mode (Miller et al., 2018) and is often described as the "transport mode of the future". (International Union for Railways, 2012; Campos et al., 2009). The European Union defines high-speed rail as lines specially built for speeds greater than or equal to $250 \mathrm{~km} / \mathrm{h} / 155 \mathrm{mph}$, or lines that are specially upgraded with speeds greater than $200 \mathrm{~km} / \mathrm{h}$ or $124 \mathrm{mph}$. (International Union of Railways, 2012). It is marketed as a sustainable alternative to air traffic. HSR technology is presented as a solution to congested roads and airports and as an efficient response for incremental demand in the coming years. In this context, the development of HSR has been a central feature of the past two decades transport infrastructure policy in the world, including for example, the European Union ( de Rus and Nombe, 2007), Korea, and China (BBC, 2017), where the high speed rail network has been rapidly developed in the past decades. The reason behind the fact that high-speed trains are getting increasingly popular is partly because high speed railway authorizes a reduction in transportation costs (Masson and Petiot, 2009), and can have positive impacts on spatial dispersion of economic activities and population (Sasaki et al., 1997), and partly because rail is a safer form of transportation than road, and building high-speed rail service will increase safety (Feigenbaum, 2013). However, high-speed rail is not completely away from dangers. After the Eschede derailment in Germany--- which killed 101 people and injured around 100 (Railway Gezette, 1998) ---, and the Wenzhou train collision--- where two high-speed trains travelling on the Yongtaiwen railway line collided on a viaduct in the suburbs of Wenzhou, Zhejiang province, China, killing 42 people and injuring another 192 (Xinhua, 2011) ---, high speed railway travel suddenly seemed "unsafe" to some people.

In addition,in the summer of 2013 a very grave train accident occurred near the Spanish town of Santiago de Compostela. A high-speed train derailed on a bend about 3 kilometres outside of the train station at Santiago de Compostela. 79 people died and more than 140 persons were injured (Railway Gezette, 2016). As verified by research, safety is of particular interest for the users of HS systems while choosing a particular HS alternative. It is always related to the perceived risk of injury and/or death due to an accident (Janic, 2003). In this context, it creates, from the legal perspective, a necessasity to establish a risk assessment requirement/mechanism in order to prevent accidents against the high speed rail. This research analyzes the EU legal framework for risk assessment vis-à-vis the high speed rail. As such, it takes use of primarily the legal analysis approach, by analyzing the legal requirements concerning risk assessment against the high speed rail and control in European Union legal system. To a more specific sphere, the legal approach includes further: a doctrinal positive legal theory approach will be carried out, that is, to seek what the risk assessment of HSR in the jurisdiction legal systems; and an legal normative approach will also be implemented: describe the way something ought to be done according to a value position.

\section{The Sources of the European Union Law Regulating Risk Assessment in High Speed Rail}

The EU has an ambitious strategy for high speed rail: the creation of a single, efficient and competitive market for high 
speed rail throughout Europe. According to the compilation by Ross, the rail system regulation requirement across the Community was mentioned as early as 1951 Treaty of Paris establishing the European Coal and Steel Community (ECSC), though it was then from a unified transport system requirement perspective. The 1957 Treaty of Rome (Art.3) called for the establishment of the CTP, including 'common rules applicable to international transport to or from the territory of a Member State' (Art. 75). After the birth of high speed rail, the EU is also increasingly --- particularly since earlier 1990s, --- involved in high speed rail system planning and constructing for the reason that it is expected as a catalyst for European development and integration (Ross, 1994). In the past decades, the regulations concerning high speed rail (though some of them regulate generally the transport system including the high speed system as well as the normal speed system ) have been issed. Among them, the Trans-European Transport Network (TEN) is a key element of European transport policy in regulating rail system, which established the interoperability principle of the trans-European high-speed rail system. Additionally, other directives and regulations involved the field of risk assessment in the high speed rail:

\begin{tabular}{|c|c|c|c|}
\hline Reference & Titres & $\begin{array}{l}\text { Date of } \\
\text { publication }\end{array}$ & $\begin{array}{l}\text { Transposition } \\
\text { deadline }\end{array}$ \\
\hline $2004 / 0051$ & $\begin{array}{l}\text { Directive 2004/51/EC of the European Parliament and of } \\
\text { the Council of } 29 \text { April } 2004 \text { amending Council Directive } \\
\text { 91/440/EEC on the development of the Community's } \\
\text { railways }\end{array}$ & $30 / 04 / 2004$ & $31 / 12 / 2005$ \\
\hline $2004 / 0050$ & $\begin{array}{l}\text { Directive 2004/50/EC of the European Parliament and of } \\
\text { the Council of } 29 \text { April } 2004 \text { amending Council Directive } \\
96 / 48 / \mathrm{EC} \text { on the interoperability of the trans-European } \\
\text { high-speed rail system and Directive } 2001 / 16 / \mathrm{EC} \text { of the } \\
\text { European Parliament and of the Council on the } \\
\text { interoperability of the trans-European conventional rail } \\
\text { system }\end{array}$ & $30 / 04 / 2004$ & $30 / 04 / 2006$ \\
\hline $2004 / 0049$ & $\begin{array}{l}\text { Directive 2004/49/EC of the European Parliament and of } \\
\text { the Council of } 29 \text { April } 2004 \text { on safety on the } \\
\text { Community's railways and amending Council Directive } \\
95 / 18 / \mathrm{EC} \text { on the licensing of railway undertakings and } \\
\text { Directive 2001/14/EC on the allocation of railway } \\
\text { infrastructure capacity and the levying of charges for the } \\
\text { use of railway infrastructure and safety certification } \\
\text { (Railway Safety Directive) }\end{array}$ & $30 / 04 / 2004$ & $30 / 04 / 2006$ \\
\hline 2001/0016 & $\begin{array}{l}\text { Directive 2001/16/EC of the European Parliament and of } \\
\text { the Council of } 19 \text { March } 2001 \text { on the interoperability of } \\
\text { the trans-European conventional rail system }\end{array}$ & $20 / 04 / 2001$ & $20 / 04 / 2003$ \\
\hline 2001/0014 & $\begin{array}{l}\text { Directive 2001/14/EC of the European Parliament and of } \\
\text { the Council of } 26 \text { February } 2001 \text { on the allocation of } \\
\text { railway infrastructure capacity and the levying of charges } \\
\text { for the use of railway infrastructure and safety } \\
\text { certification }\end{array}$ & $15 / 03 / 2001$ & $15 / 03 / 2003$ \\
\hline $2001 / 0013$ & $\begin{array}{l}\text { Directive 2001/13/EC of the European Parliament and of } \\
\text { the Council of } 26 \text { February } 2001 \text { amending Council } \\
\text { Directive 95/18/EC on the licensing of railway } \\
\text { undertakings }\end{array}$ & $15 / 03 / 2001$ & $15 / 03 / 2003$ \\
\hline
\end{tabular}




\begin{tabular}{|l|l|l|l|}
\hline $\mathbf{2 0 0 1 / 0 0 1 2}$ & $\begin{array}{l}\text { Directive 2001/12/EC of the European Parliament and of } \\
\text { the Council of 26 February 2001 amending Council } \\
\text { Directive 91/440/EEC on the development of the } \\
\text { Community's railways }\end{array}$ & & $15 / 03 / 2003$ \\
\hline $\mathbf{1 9 9 6 / 0 0 4 8}$ & $\begin{array}{l}\text { Council Directive 96/48/EC of } 23 \text { July } 1996 \text { on the } \\
\text { interoperability of the trans-European high-speed rail } \\
\text { system }\end{array}$ & 17/09/96 & $08 / 04 / 99$ \\
\hline $\mathbf{1 9 9 5 / 0 0 1 8}$ & $\begin{array}{l}\text { Council Directive 95/18/EC of } 19 \text { June 1995 on the } \\
\text { licensing of railway undertakings }\end{array}$ & $27 / 06 / 95$ & $27 / 06 / 97$ \\
\hline $\mathbf{1 9 9 1 / 0 4 4 0}$ & $\begin{array}{l}\text { Council Directive 91/440/EEC of 29 July 1991 on the } \\
\text { development of the Community's railways }\end{array}$ & $24 / 08 / 91$ & $01 / 01 / 93$ \\
\hline
\end{tabular}

Figure 1. Transport directives of the European Union: Rail transport

Among the above laws, the Railway Safety Directive is most important. The Railway Safety Directive contains a number of concrete instruments for the effective management of railway safety, such as harmonised safety certification, vehicle authorization, supervision, or risk assessment. They are meant to support the overarching objective to create an internal market for railway vehicles and train services across Europe having no detrimental impact on railway safety. The revised Directive should contain some additional elements enabling an effective safety management at EU level, notably tangible safety targets, common occurrence reporting, harmonised supervision and improved risk management at EU level. The long-term objective of the Railway Safety Directive is the gradual reduction of national rules in order to move towards a more harmonised European approach to safety. Many of these national rules are redundant as common requirements have now been enacted at EU level. It is therefore timely to review and clarify the scope that remains for national safety rules in the Member States. Also, as substantiated by Agency reports and feedback from the sector, there is a need to increase transparency in how national safety rules are established, published and made available.

All those operating the railway systems in the European Union are subject to the legal system above. This implies firstly that high speed rail is under regulation by the system; and secondly, there is an absence of a legal system tailored the high speed rail (this will be discussed further in later parts).

The European Union Agency for Railways is established by Regulation (EU) 2016/796 (Article 1.1). Functionally, it is responsible for developing common safety targets and common safety methods, including among other things, Common safety method for risk evaluation and assessment. Generally, the European Union Agency for Railways made the CSM Rrisk Assessment in order to harmonise processes for risk evaluation and assessment and the evidence and documentation produced during the application of these processes (Koursi, 2007). In this way, the EU effectively hoarmonise the way (together through ) how the risk assessment shall be carried by the duty-holder. In addition, by applying a common process, it will be easier for an assessment undertaken in one EU Member State to be accepted in another with the minimum of further work. This is referred to as mutual recognition, for example, discussed by Scharpf (1994). Also, the Commission Implementing Regulation (EU) No. 2015/1136 completes the revision of the CSM for risk evaluation and assessment initiated by the Commission Decision of 12.10.2010 (the Mandate).

Common safety method for risk evaluation and assessment provides that: (a) if the change has an impact on safety the proposer must decide on whether it is significant or not by using criteria in the CSM Risk Assessment. (b) If the change is significant the proposer must apply the risk management process. If the change is not significant, the proposer must keep a record of how it arrived at its decision. In order to supervise the duty-holder's risk assessment obligation above, an assessment body must carry out an independent assessment of how the risk management process is applied and the results from the risk management process. The assessment body must meet criteria set out in Annex II of the CSM Risk Assessment. This includes meeting the requirements of the ISO/IEC 17020:2012 and being accredited or recognised.

As mentioned above, this CSM gives a harmonised framework for the risk assessment process. This is realized through the prescription of hazard identification, risk analysis and risk evaluation, which will be also dicussed later. Specifically speaking, the risks include: (a)individual risks relating to passengers, staff including the staff of contractors, level crossing users and others, and, without prejudice to existing national and international liability rules, individual risks relating to unauthorised persons on railway premises (Article 7.4(a) of Directive 2004/49/EC); (b) societal risks. The social risks are included,. But what is social risks are not clearly defined, instead left to Member States. Furthere more, it requires the Member States to ensure the control of all risks associated with the activity of the infrastructure manager or railway 
undertaking, including the supply of maintenance and material and the use of contractors (Article 9.2).

Next to CSM Risk Assessment, The European Union Agency for Railways also introduced the Control Command and Signalling (CCS) TSI sets out the framework for the harmonization of the train detection, communication and train control systems on the High Speed and conventional railway network in Europe (European Union Agency for Railways, 2016). In addition, recommendations relating to the risk assessment of buffer stops, arresting devices and

end impact walls are set out in this instrument. It also provides practical and attentive assessment services is to high speed railway undertaking through the requirements of standards and norms to the processes of high speed railway undertaking.

Safety supervision is assured at the national level by the National Safety Authorities, with two main instruments defined in the railway safety directive as audits and inspections, which will be discussed later. However, this does not mean that the EU law is doing nothing. As a matter of fact, the Railway Safety Directive requires that serious accidents are independently investigated by an independent National Investigation Body (NIB).

In 2013, the European Railway Agency signed administrative arrangements with the Intergovernmental Organisation for International Carriage by Rail (OTIF) and the European Commission's Directorate-General for Mobility and Transport (DG Move), establishing more effective collaboration and coordination. This will allow better coordination between the EU legislation on railway safety, which is mainly aimed at preventing the occurrence of accidents, and the RID requirements, which is mainly concerned with the classification of substances, their means of containment and loading/ unloading requirements. The Agency has also established a collaboration with the UNECE Joint Meeting of the ADR/RID/ ADN experts on the carriage of dangerous goods.

\section{Roles of Different Actors in High Speed Rail Risk Assessment}

Based on the above, it can be seen that the actors involved in the risk assement are: the infrastructure managers and railway undertakings, Naitonal Safety Authorities, Investigation Bodies. Generally, the first two have the "full responsibility" for the safety of the system. The rest two are national bodies responsible for supervising whether the first two have carried out their risk assessment obligations. The roles of the four bodies will be examined as follows:

\subsection{The Infrastructure Managers' Risk Assessment Obligations}

According to Directive 2004/49/EC, 'infrastructure manager' means any body or undertaking that is responsible in particular for establishing and maintaining railway infrastructure (Article 3 (b)). The sector infrastructure management has been separated from railway undertakings so that competition could grow within the railway service sector (Directorate-General For Internal Policies: Policy Department Budgetary Affairs, 2015; Nash, 2010; Commission of the European Communities, 2006). Due to this, the management is seen as an independent entity bearing obligations in the European legal system, which is reflected in, inter alia, the Preamble (5) of the Directive 2004/49/EC, reading as: "All those operating the railway system, infrastructure managers and railway undertakings, should bear the full responsibility for the safety of the system, each for their own part".

To that end, the infrastructure mangers are obliged to evaluate the risk either quantitatively or qualitatively, or both when necessary (Annex 1, 2.5.1 of Regulation (EU) No 402/2013). They should cooperate in implementing risk control measures. Specifically speaking, they should apply the methods for monitoring set out in the common safety methods as mentione before, which adopts the prescription of hazard identification, risk analysis and risk evaluation, as demonstrated in the follow picture. 


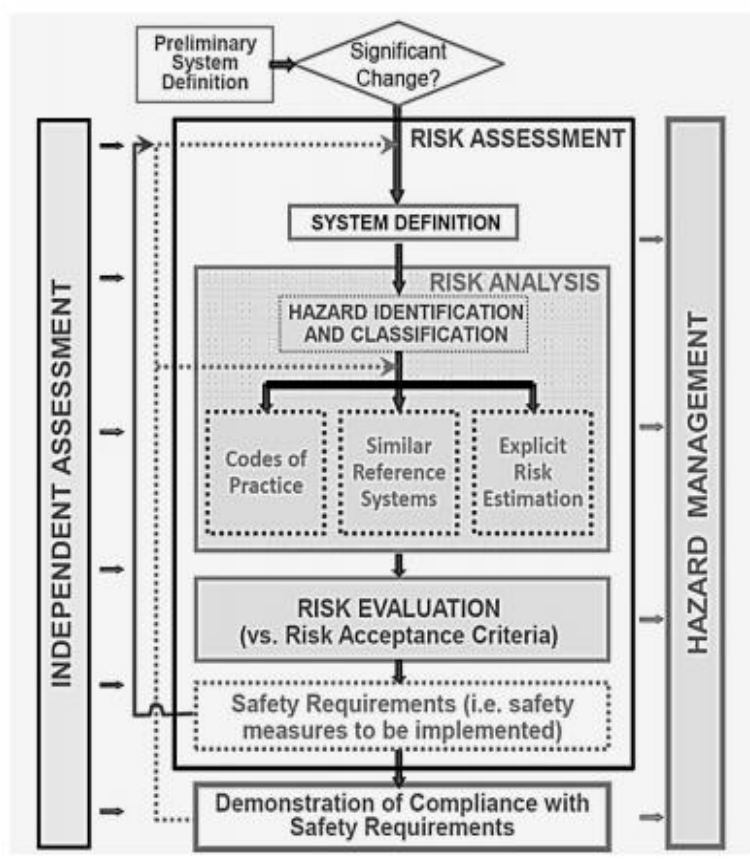

Picture 1. the Risk Assessment Mechnism Provided by the CSM (Farrington-Darby, 2005)

The CSMs gives a broad framework for the use of risk assessment methodologies to assess changes to the high speed railway system. Here it is also worth mentioning that, based on the CSM regulation, Member States can make their own standards. For example, the UK's Common Safety Method for risk evaluation and Assessment Guidance on the application of Commission Regulation (EU) 402/2013, which impose any specific tools and techniques to be used in an risk estimation against rail in order to carry out the requirments in the CSM regulation. In this regard, the infrastructure mangers' obligation arising from common safety manage regulation might be different across the member states. Yet, the difference is not significant as the obligations are based on the same requirements.

Specifically speaking, the CSM regulation requires the high speed infrastructure managers the risk assessment obligations as follows: (1) identifying the hazardous events which have the potential to cause injury or death to passengers and the high speed rail workers; (2) identifying the precursors (i.e. the component, sub-system or system failures, physical effects, human error failures or operational conditions), which can result in the occurrence of each hazardous event; (3) identifying the control measures that are in place to control or limit the occurrence of each precursor that cannot be eliminated;

Furthermore, the high speed rail infrastructure managers also have the obligation to implement a safety management system, fulfilling Community requirements and containing common elements (preamble (13) of Directive 2004/49/EC). In order to able to keep how the requirement is in hand, the European system further requires that the information on safety and the implementation of the safety management system should be submitted to the safety authority in the Member State concerned (preamble (13)).

Next to the above, every infrastructure manager has a key responsibility for the safe design, maintenance and operation of its rail network (preamble (13) ). In addition, the Member States are asked to make a clear distinction between this immediate responsibility for safety and the safety authorities' task of providing a national regulatory framework and supervising the performance of the operators.

Also importantly, the infrastructure managers bear the obligation to esbalish the safety management system (Article 9). According to the EU law, the 'safety management system' means the organisation and arrangements established by an infrastructure manager or a railway undertaking to ensure the safe management of its operations (Article 3 (i)). In order to be allowed to manage and operate a rail infrastructure the infrastructure manager must obtain a safety authorization from the safety authority in the Member State where he is established. The safety authorisation shall comprise the following elements: (a) authorisation confirming acceptance of the infrastructure manager's safety management system; and (b) authorisation confirming acceptance of the provisions of the infrastructure manager to meet specific requirements necessary for the safe design, maintenance and operation of the railway infrastructure including, where appropriate, the 
maintenance and operation of the traffic control and signaling system (Article 11.1).

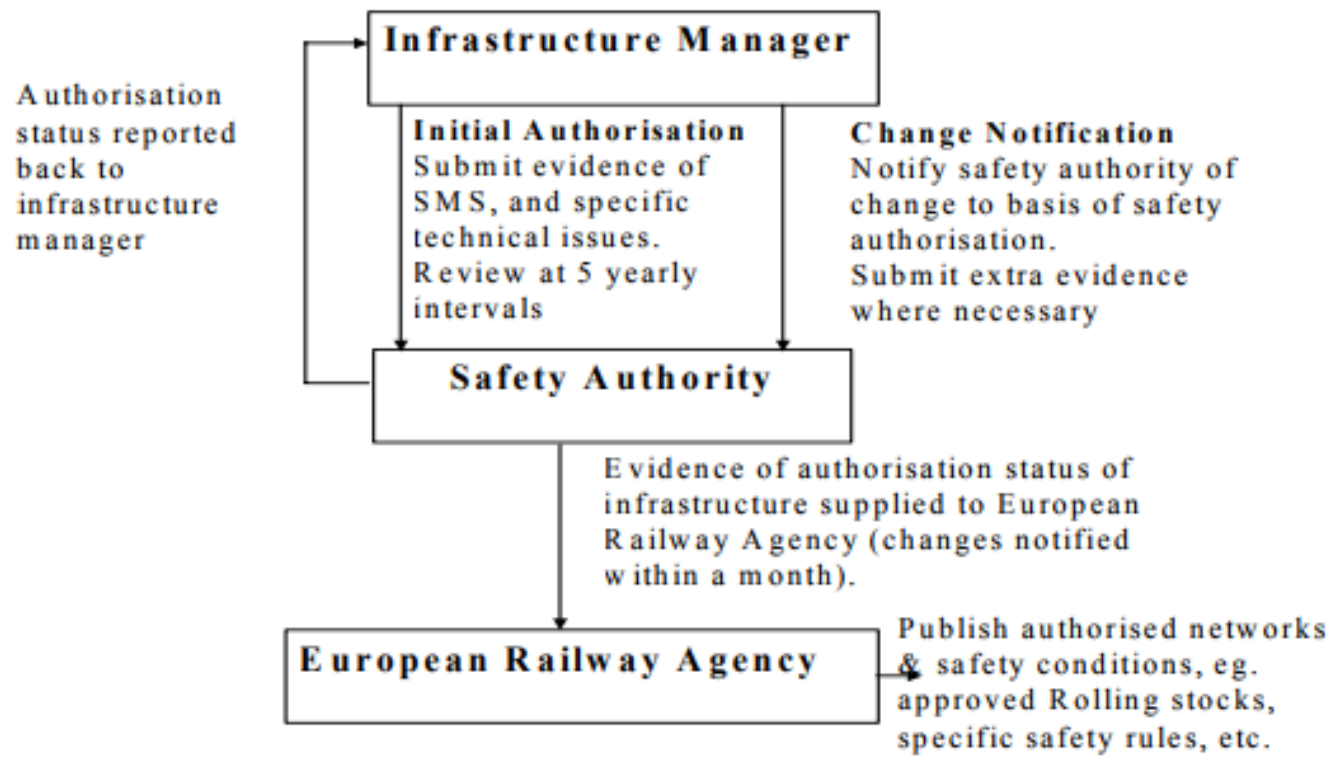

Figure 2. Safety Authorisation Information Flow for Infrastructure Managers (Koursi, 2007)

The safety authority in the above Figure means national safety authority, whose role will be discussed in later parts. The authorization is an important instrument, because by it provides control by the national govenments over the compenetence of infrastructure manager, including among other things, the risk assessment. Furthermore, according to the compilation by Koursi, the infrustucture's safety authorization must be renewed, at the latest, every five years after the intial authorization by the safety authority. This requirement is also reflected in the above figure. The law obligates the infrutsture manager to inform the relevant safety authroties, without delay, in the event of any substantial changes to the infrastructure, signaling or energy supply or to the principles of its operation and maintenance (Koursi, 2007).

Lastly, the manager is obliged to submit ananual report, which at least partly concerns the risk assessment. Specifically speaking, all infrastructure managers shall submit safety reports. These reports include: (a) information on how the organisations corporate safety targets are met; the results of planned safety activity; development of national safety indicators; (c) the results of internal safety auditing; (d) observations on deficiencies and malfunctions of railway operations and infrastructure management that might be relevant for the safety authority (Article 9.4 of the Directive 2004/49/EC).

Although the EU law prescribe the above reuiqrements towards the risk assessment obligations vis-à-vis the high speed rail infrastructure, it is, however, mostly insufficient because it fail to prescribe, at the EU level, the consequences against the infrastucturers and the railway understakings in case where they fail to carry out the above requirements. This has the risk to leading to varying sanctions against law breaches by infrastructure managers.

\subsection{Railway Undertakings' Risk Assessment Obligations}

The Directive 2001/14/EC defined the "railway undertaking" as any other public or private undertaking, the activity of which is to provide transport of goods and/or passengers by rail on the basis that the undertaking must ensure traction(Article 2.(k)). Railway undertakings in the European Union Member States are including for example, Deutsche Bahn AG (DB) (Note 1), the French SNCF (Note 2) and the Italian Ferrovie dello Stato Italiane S.p.A. (Note 3), the Dutch Railway ( Note 4). Similar to what is noted in the role of the infrastructure manager, there is also a legislative requirement for the railway understakings. The legal basis for that railway understakings are seen as being responsible for risk assessment lies in the Directive 2004/49/EC. Here, it discusses the risk assessment role of the railway understaking operating on the high speed rail.

Firstly, they are obliged to establish a safety management system--- the organisation and arrangements to ensure the safe management of the operations. They are also obliged to implement the safety management system during their rountine operations. (Preamble (13)). The safety management has a risk assessment manger as its integral part. Secondly, the Railway Safety Directive requires the railway undertakings to hold a safety certificate issued by the national safety 
authority to access the railway infrastructure (Preamble (15)). The safety certificate should give evidence that the railway undertaking has established its safety management system (including risk assessment) and is able to carry out the risk assessment and comply with the relevant safety standards and rules (Preamble (15)). These requirements form the risk assessment measure: the safety certification of railway undertakings. As part of the certification process, national safety authority assesses its Safety Management System. Thirdly, like what is examined in the role of the infrastructure managers, the high speed rail understakings have the obligation to carry out the common safety methods as well. The application of the common safety methods on risk assessment will enable the railway understaking to control the risks that arise from changes to the railway system.

\subsection{National Safety Authorities}

The Railway Safety Directive required the Member States to set up two national authorities with defined competences in the field of railway safety: national safety authorities (NSA) and national investigating bodies (NIB). The role of NIB will be dicussed later. The NSAs have the task of monitoring the safety regulatory framework and supervising railway safety. They issue the safety authorizations to infrastructure managers and safety certificates to railway undertakings of high speed rail. The Regulation (EU) No1077/2012 requires the National Safety Authorities (NSAs) to oversee the safety performance of the railway undertakings and infrastructure managers operating in their respective Member State. For that purpose, the National Safety Authorities can adopt various techniques for supervision, ranging from management system audits to inspections in the field as the NSAs are imposed by the railway safety directive the two main instruments: audits and inspections. NSAs often use a combination of audits and inspections in their annual supervision plans to ensure that appropriate risk assessment requirements are met. Specifically speaking, the inspectors shall carry out inspections against the risk assessment obligation of the duty-holders (the above two actors) as irregular checks of the specific procedures or operations. The safety audits are typically the result of longer-term planning and follow a well-established comprehensive procedure. They are also required to do so with the "greatest possible professional integrity and the greatest possible technical competence" (Article 1, Annex VII, Directive 2001/16/EC). Meanwhile, the Directive also granted the inspectors free from, among other things, financial pressure. That is to say, they shall be paid to perform inspections. National safety authorities should coordinate their supervision activities against risk assessment in relation to high speed railway undertakings established in different Member States, and should share information among themselves and, where appropriate, with the European Railway Agency (Article 28, in Preamble of Directive (EU) 2016/798). Lastly, the NSAs are also oliged to publish the safety reports. However this requirement is not prescribed in the legal system at the EU level, instead it is left to the Member States to require so. After examing, it is argued that almost all the Member States have expreslly provided this requirement, except some eastern European countries, such as Poland, Romania, Bulgaria, and Latvia.

\subsection{Investigation Bodies}

The revision of the first Regulation (EC) No352/2009 on the CSM for risk assessment clarifies the requirements for the independent assessment body referred to in Article 6 of that Regulation. This is legal basis for the member states to establish the investigation bodies. Furthermore, Regulation (EU) No. 402/2013 defines the criteria to be fulfilled by the assessment body and the necessary requirements for the accreditation or recognition of its competence in order to achieve a similar quality of independent assessment regardless on whether the assessment body is accredited or recognised.

The Investigation Bodies are permanent bodies, independent of rail actors and separate from the judicial inquiry, in charge of investigating serious accidents. Regarding the detailed compentence of the investigation bodies, the EU law set up a general requirement. The detailed requirements are left to Member States to regulate. In building the domestic legal framework, the investigation bodies of Member States are required to ensure that the responsibility for the safe operation of the railway system and the control of risks managers and railway undertakings. ( preamble (5) of Directive 2004/49/EC). Furthermore, the national law ought to include an obligation to implement necessary risk assessment and risk control measures, to establish safety management systems (preamble (5) of Directive 2004/49/EC). However, the information available to the ERA also shows that the approach to supervision differs substantially between Member States

\section{The Legal Prevention Measures}

Based on the above examination, the legal measures used to promote risk assessment are here concluded in order to have a more clear picture of the European system.

\subsection{Safety Management System}

One of the elements of the EU law is the reuiqment for a safety management system which meets certain criteria and is certified by the safety authority. And both the infrasture manager and understakings of high speed railway are obliged to so do. This legal instrument is important to risk assessment, because it is per se an integral part of the safety management system and as such, the risk assessment becomes the routine management task of the above two parties 
required by law. This is not only in line with the purpose of risk assessment, that is to identify the control measures needed to control risks in the high speed rail, but also in line with the fact that risk assessments form the foundation of safety management systems.

\subsection{Safety Certification}

The EU's ultimate aim is to establish a common safety certificate with Community validity at, among other things, the legal level. This is well reflected in the Rail Safety Directive (preamble (15)). To this end, the EU system adopts the certificate instrument. The Railway Safety Directive requires the railway undertakings (RUs) to hold a safety certificate issued by the national safety authority (NSA) to access the railway infrastructure. The purpose of the safety certificate is to provide evidence that the railway undertaking has established its safety management system and can meet requirements laid down in TSIs and other relevant Community legislation and in national safety rules in order to control risks and operate safely on the network (Article 10.1).

Through the certification instrument, the legal system can empower the high speed rail safety authority to control whether the invovlving parties meet the safety requirements provided by law , so as observed in the EU system. Meanwhile, risk assessment is a dynamic process that enables the high speed infrasture mangers and understakings to proactively manage high speed risks. With the development of high speed rail safety technology, the risks assessment knowledge is continuously developing correspondingly. Completing a certificate program indicates that safety certification holderare committed to staying current in the high speed rail risk assessment field, have attained a higher level of expertise and have the discipline to work toward a specific safety goal. While there has been a sound progress in the implementation of the legal requirement, there is a need for reflection on how to further harmonise the work of the certification bodies. Also, the performance of certification issurance is different among the Member States, which is presented in the following picture. The part A safety certificate is valid throughout the EU; while the part B certificate is vaild exclusively in the Member State where the certificate is issued.

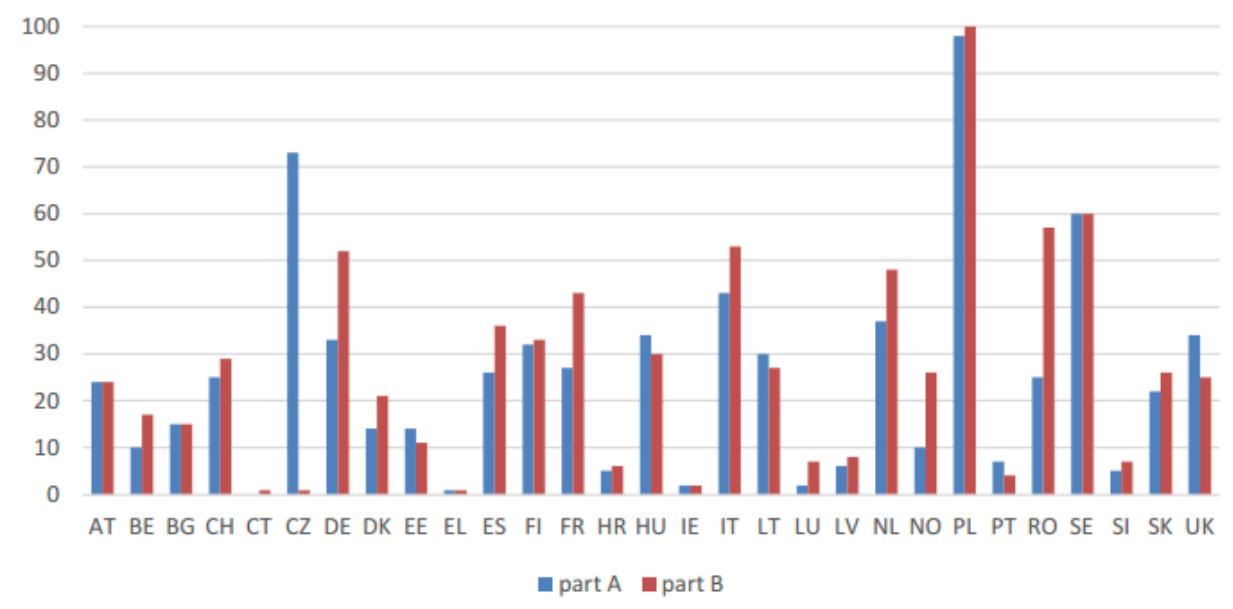

Picture 2. Number of valid Safety Certificates — Part A and B per Member State (ERADIS - 1.1.2016) (European Railway Accident Information Links, 2017)

\subsection{Common Safety Targets (CSTs)}

The Safety Directive presents Common Safety Targets (CSCTs) as the safety levels that must at least be achieved by different parts of the railway system in relation to different groups of individuals that are using the railways or being exposed to risks arising from high railway traffic indirectly. The CSM applies to 'any change of the railway system in a Member State ... which is considered to be significant within the meaning of Article 4 of this Regulation [ie, the CSM itself].In nature, CSTs are quantitative measures of risk assessing whether the current safety levels of the railways in the Member States are at least maintained.

As compiled by RSSB, a british railway safety counseling company, the CSM facilitates 'access to the market for rail transport services' through harmonisation of:

'the risk management processes used to assess the safety levels and the compliance with safety requirements; the exchange of safety-relevant information between different actors within the rail sector in order to manage safety across the different interfaces which may exist within this sector; the [evaluation of] evidence resulting from the application of a risk management process.' (RSSB, 2017) 
The proposer of a change in high speed rail operation is responsible for applying the risk management process set out in the CSM. The national safety authority --- in this seeting as the assessment body---, then provides 'an independent assessment of the correct application of the risk management process'.

From the European Union's perspective, the reason to develop Common Safety Targets lies in that it can assure a short term control of safety performances and a long term convergence of safety performance in Europe, through the use of common ways of measuring and assessing safety performance on a macro level (European Union Agency For Railways, 2017).

Functionally speaking, the Common safety targets lay out detailed requirements for the risk assessment. It is also noted that CSTs are provided in the form of EU regulation, a binding legislative act, and as such it must be applied in its entirety across the EU. That implies that the risk assement requirements of CSTs can be (and shall be) directly implemented by member states. Nonetheless, there is noted an absence of a enforcement/coordination body at the EU level. As such it is arguable that the responsibility is still largely accorded to national authorities, namely, to the member states to deal with.

\subsection{Speed Limit}

In adidition to the above legal instruments, the EU law also takes use of speed limit to ensure safety. Commercial speed in many services is often limited due to, for example, proximity to densely urbanized areas (to ease the impact of noise and minimize the risk of accidents), or the existence of viaducts or tunnels (where speed must be reduced to $160-180 \mathrm{~km} / \mathrm{h}$ for safety reasons). This creates the high speed rail infrastructure managers and understakings a risk assessment towards speed control according to the legal requirements. Any accidents involving dangerous goods may have catastrophic consequences in terms of human victims or environmental damage. This is why, in addition and without prejudice to the general EU legislation on railway safety, specific requirements on the classification, containment and loading/ unloading of substances apply. These requirements are definedin the RID (21) which is transposed in EU legislation by the EU Directive 2008/68 on the inland transport of dangerous goods (European Railway Accident Information Links, 2014).

\section{Discussion}

Based on the above research, it can be concluded that an effective legal norm for risk assessment in the high speed rail from the EU law experience shall be as follows: Firstly, the EU system has established a comprehensive railway risk assessment legal mechanism. It provides an effective framework imposing obligaitons on different involved actors and prescribing a series instruments to ensure the obligations are well carried out within the objective of safety. Secondly, high speed rail system's operation is a complicated management subject involving environmental issues, train schedules, safety, rolling stock and infrastructure reliability (transport infrastructures are critical and vulnerable) (Transport Research \& Innovation Portal, 2017). As such, the EU law takes use of mainly general requirements as observed in section 3, while the detailed rules are left to member states as well as the actors to establish.

Meanwhile, throughout the above analysis, some weaknesses have been also found: Firstly, there is a lack of specialized high speed rail legsialtion at the EU level. This leads to that the risk assessment is regulated by rules scattered aomong the railway. A consequence is that the risk assessment requirement fails to be built on the full consideration of risks particularly related to high speed rail. Secondly, although the safety certification is widely adopted in the EU legal system, this legal instrument has its advantages in keeping the risk assessment. however, as pointed out before, the safety certification is not harmonized in throughout EU. Thirdly, risk assessment method. Because it is set up in the form of law, it is mandatory to be carried out. Meanwhile, the method consists of detailed rules, and as such, is operational for the duty holders. However, the approach which relies on detailed rules is not competent to respond swiftly to technology deveolpments. As is known, the development in high speed rail is usually seen as impressively rapid. Therefore, the detailed ruels can easily become outdated. A possible solution might be that the risk assessment mehod swift to general rules, leaving implementing rules instead to high speed rail industry body, which can on the one side, it can create detailed rules on the basis of the requirements set up in the risk assessment method, and on the other side, it can also update rules in a more timely fashion. Fourthly, as examined in part 2, the risk assessment role of infrastructure managers are obviously larger than the railway understakings. The imbalanced obligation status quo is not reasonable, because the understakings of the high speed rail know the risks better as they operate the trains in a routine fashion.

In conclusion, it could be argued that in the context that risk assessment in high speed rail encouters various tensions nowadays, the EU legal system is constantly endeavoring to find a balance by constructing theoretically rational and reasonable legal framework promoting risk assessment in the high speed rail on the one hand, while leaving room for other parties to regulate on the other hand. 


\section{Acknowledgments}

This research is supported by:

1. Jiangsu Research Funding of Philosophy and Social Sciences, 2018SJA0922

2. Jiangsu Shuangchuang Research Program (Shuangchuang PhDs), Year 2018

3. Jiangsu Normal University Teachers' Research Funding 18XWRS011

4. Jiangsu Normal University Booking Publishing Funding JYJC202003

\section{References}

BBC, 2017. Inside China's incredible high-speed rail network. Retrieved May 5, 2020, from http://www.bbc.com/future/story/20170605-inside-chinas-incredible-train-network

Campos, J., de Rus, G., \& Barrón, I. (2009). Some stylized facts about high speed rail around the world. Transport Policy, 16(2), 19-28. https://doi.org/10.1016/j.tranpol.2009.02.008

de Rus, G., \& Nombe, G. (2007). Is investment in high speed rail socially profitable? Journal of Transport Economics and Policy, 41(3), 3-23.

Directorate-General For Internal Policies: Policy Department Budgetary Affairs. (2015). The Results and Efficiency of Railway Infrastructure Financing within the European Union. Retrieved June 12, 2020, from http://www.europarl.europa.eu/RegData/etudes/STUD/2015/552308/IPOL_STU(2015)552308_EN.pdf

European Railway Accident Information Links. (2014). Railway Safety Performance In The European Union. Retrieved June 27, 2020, from http://www.era.europa.eu/document-register/documents/spr2014.pdf

European Railway Accident Information Links. (2017). Railway Safety Performance in the European Union 2016. Retrieved June 20, 2020, from https://erail.era.europa.eu/documents/SPR.pdf

European Union Agency for Railways. (2016). The European Union Agency for Railways Project on the evolution of the radio communication system for railways. Retrieved June 1,2020, from

http://www.era.europa.eu/Document-Register/Documents/ERA\%20Program\%20for\%20the\%20evolution\%20of\% 20the\%20radio\%20communicationsystem\%20for\%20railways.pdf

European Union Agency For Railways. (2017). Retrieved June 20, 2020 from http://www.era.europa.eu/Core-Activities/Safety/Safety-Performance/Pages/Common-Safety-Targets.aspx

Farrington-Darby, T., Pickup, L., \& Wilson, J. R. (2005). Safety culture in railway maintenance. Safety Science, 43(2), 39-60. https://doi.org/10.1016/j.ssci.2004.09.003

Feigenbaum, B. (2013). High-Speed rail in Europe and Asia: lessons for the United States. Retrieved May 10, 2020, from http://reason.org/files/high_speed_rail_lessons.pdf

International Union of Railways. (2012). General Definitions of Highspeed. Retrieved May 5, 2020, from http://www.uic.org/spip.php?article971

International Union of Railways. (2012). High speed rail fast track to sustainable mobility. Retrieved May 5, 2020, from http://uic.org/IMG/pdf/high_speed_brochure.pdf

Janic, M. (2003). Multicriteria evaluation of high-speed rail, transrapid maglev and air passenger transport in Europe. Transportation Planning and Technology, 26(2), 491-512. https://doi.org/10.1080/0308106032000167373

Koursi, E., Mitra, S., \& Bearfield, G. (2007). Harmonizing safety management systems in the European railway sector. Safety Science Monitor, 11(4), 14-28.

Masson, S., \& Petiot, R. (2009). Can the high speed rail reinforce tourism attractiveness? The Case of The High. Technovation, 29(2), 611-617. https://doi.org/10.1016/j.technovation.2009.05.013

Miller, T., Levy, D. T., \& Swedler, D. I. (2018). Lives saved by laws and regulations that resulted from the Bloomberg road safety program. Accident Analysis \& Prevention, 113(4), 131-136. https://doi.org/10.1016/j.aap.2018.01.014

Nash, C. (2010). European rail reform and passenger services: the next steps. Research in Transportation Economics, 29(2), 204-211. https://doi.org/10.1016/j.retrec.2010.07.025

Railway Gezette. (1998). Eschede: questions and consequences. Retrieved May 12, 2020, from http://www.railwaygazette.com/news/single-view/view/eschede-questions-and-consequences.html

Railway Gezette. (2016). Concerns raised over Santiago de Compostela crash investigation. Retrieved May 12, 2020, from 
http://www.railwaygazette.com/news/high-speed/single-view/view/concerns-raised-over-santiago-de-compostela-c rash-investigation.html

Ross, J. F. L. (1994). High-speed Rail: Catalyst for European integration? Journal of Common Market Studies, 32(1), 191-214. https://doi.org/10.1111/j.1468-5965.1994.tb00493.x

RSSB. (2017). CSM on risk evaluation and assessment. Retrieved June 20, 2020, from https://www.rssb.co.uk/improving-industry-performance/the-legislative-framework/csm-for-risk-evaluation-and-as sessment

Sasaki, K., Ohashi, T., \& Ando, A. (1997). High-speed rail transit impact on regional systems: does the Scharpf, F.W. (1994). Community and autonomy: Multi-level policy-making in the European Union. Journal of European Public Policy, 24(1), 219-242. https://doi.org/10.1080/13501769408406956

Shinkansen contribute to dispersion? The Annals of Regional Science, 31(2), 77-98

Transport Research \& Innovation Portal. (2017). Risk Assessment and Management for High-Speed Rail Systems. Retrieved June 30, 2020, from http://www.transport-research.info/project/risk-assessment-and-management-high-speed-rail-systems

Xinhua. (2011). Death toll from China's train crash rises to 39, including two Americans. Retrieved May 12, 2020, from News.xinhuanet.com

\section{Notes}

Note 1. Deutsche Bahn AG is a German railway company. Headquartered in Berlin, it is a private joint-stock company (AG), with the Federal Republic of Germany being its single shareholder.

Note 2. SNCF is France's national state-owned railway company and manages the rail traffic in France and the Principality of Monaco.

Note 3. Ferrovie dello Stato Italiane S.p.A is a government-owned holding company that manages infrastructure and services on the Italian rail network.

Note 4. Nederlandse Spoorwegen is the principal passenger railway operator in the Netherlands.

\section{Copyrights}

Copyright for this article is retained by the author(s), with first publication rights granted to the journal.

This is an open-access article distributed under the terms and conditions of the Creative Commons Attribution license which permits unrestricted use, distribution, and reproduction in any medium, provided the original work is properly cited. 